\title{
Mengulik Euforia Amnesti Pajak: Hukum-APBN-Utang-Pajak (Studi Kasus Kantor Pelayanan Pajak Pratama Kabupaten X) \\ Whedy Prasetyo ${ }^{1}$
}

\author{
Universitas Jember, Jl. Kalimatan No. 37 Tegalboto Kotak Pos 125 Jember 6812
}

\section{A R T I C L E I N F O}

\author{
Article history: \\ Received 1 Mei 2018 \\ Revised 30 Mei 2018 \\ Accepted 8 Juni 2018
}

\section{Keywords:}

Tax amnesty, law, tax compliance, revenue, and debt.

\begin{abstract}
A B S T R A C T
This study aims to investigate Law. 11 of 2016 on Tax Amnesty dated July 1, 2016 which aims to increase tax revenues and encourage the transfer of assets abroad to the country (asset repatriation). A case study on Tax Office Primary Regency Xwith a qualitative approach is used in this study by showing the response of the presence of PSAK 70 on the Implementation of Asset Accounting (Treasures) and Liabilities (Debt) Tax Amnesty in a proportional perspective. The result is the growth of tax compliance in the motivation and mental attitude of the taxpayer through integrity, responsibility, discipline, accuracy, cooperation, honesty, visionary, motivation and attitude to achieve tax functions as Budgeter, Regulern, Democracy, and Redistribution in tax amnesty. These four functions are a manifestation of the Law-APBN-Debt-Tax on tax realization targets, therefore tax is expected to be a form of public awareness (voluntary compliance) in contributing to the State through self assessment. Finally, the function of tax amnesty can be an economic tool for the welfare of the people, one of the sources of development financing, to encourage economic growth through the current development policy and it means to create job opportunities and other economic and business opportunities. So that the two parties between the government and WP have a synergistic relationship in recording and reporting the amount of taxes that become obligations, toward a fair tax revenue structure.
\end{abstract}

\begin{abstract}
A B S T R A K
Penelitian ini bertujuan mengulik UU No. 11 Tahun 2016 tentang Pengampunan Pajak yang tertanggal 1 Juli 2016 yang bertujuan untuk meningkatkan penerimaan pajak dan mendorong pengalihan aset di luar negeri ke dalam negeri (repatriasi aset). Studi kasus pada Kantor Pelayanan Pajak Pratama Kabupaten X dengan pendekatan kualitatif digunakan dalam penelitian ini, untuk memperlihatkan respon hadirnya PSAK 70 tentang Implementasi Akuntansi Aset (Harta) dan Liabilitas (Utang) Pengampunan Pajak dalam prespektif proporsional. Hasilnya tumbuhnya kepatuhan pajak dalam motivasi dan sikap mental wajib pajak melalui integritas, tanggung jawab, kedisiplinan, ketepatan, kerja sama, kejujuran, keberanian, pandangan hidup, motivasi dan sikap ini untuk mencapai fungsi pajak sebagai Budgeter, Regulern, Demokrasi, dan Redistribusi dalam amnesti pajak. Keempat fungsi ini sebagai wujud prespektif Hukum-APBN-Utang-Pajak tentang target realisasi pajak, oleh karenanya pajak diharapkan menjadi wujud kesadaran masyarakat (voluntary compliance) dalam memberikan kontribusi terhadap Negara melalui self assessment. Akhirnya, fungsi amnesti pajak dapat menjadi alat perekonomian yang mensejahterakan masyarakat, salah satu sumber pembiayaan pembangunan, mendorong pertumbuhan ekonomi lewat kebijakan pembangunan yang berjalan dan itu berarti mampu menciptakan kesempatan kerja dan berusaha serta sarana perekonomian lainnya. Sehingga dua pihak antara pemerintah dan WP memiliki hubungan yang sinergi dalam mencatat dan melaporkan jumlah pajak yang menjadi kewajibannya, menuju struktur penerimaan pajak berkeadilan.
\end{abstract}

\section{PENDAHULUAN}

Aturan detail tax amnesty ditunggu sebagai sumber pendapatan terbaru pemerintah, namun disatu sisi jangan jadi euforiayang berlebihan sehingga 
menimbulkan dampak negatif (Pernyataan Presiden Joko Widodo, MetroTv, 19 Juli 2016, 09.57 WIB).

Wacana tax amnesty ${ }^{1}$ mulai disuarakan disaat Mardiasmo selaku Wakil Menteri Keuangan Republik Indonesia sebagai pejabat penganti Dirjen Pajak menyampaikan kepada pemerintah agar melaksanakan tax amnesty, tujuannya untuk menutup defisit negara di tahun 2015 (pajak.go.id, 2015). Menurut beliau bahwa jika tax amnesty dilaksanakan maka pendapatan negara sebesar Rp. 1.822,5 triliun dapat dipenuhi dari pajak sebesar Rp. 1.546,7 triliun. Artinya target pajak di tahun 2016 dapat terpenuhi. Wacana ini semakin meruncing pada saat "mencuatnya" adanya "Panama Paper". Salah satu akibat dari Panama Paper adalah mulai terkuak bahwa Wajib Pajak (WP) Indonesia banyak yang mengungsikan sebagian besar hartanya di negara lain yang tentunya bebas dari pajak dan mempunyai tarif pajak yang lebih rendah. Program pengampunan pajak ini sudah resmi dijalankan. UU No. 11 Tahun 2016 tentang Pengampunan Pajak yang ditandatangani Presiden Joko Widodo pada tanggal 1 Juli 2016 antara lain bertujuan untuk meningkatkan penerimaan pajak dan mendorong pengalihan aset di luar negeri ke dalam negeri (repatriasi aset). Aset tersebut selama ini tidak dilaporkan sehingga tidak dikenai pajak. Padahal, semua tambahan kemampuan ekonomi (penghasilan) wajib pajak, baik yang berasal dari Indonesia maupun dari luar Indonesia harus dikenai pajak.

UU Pengampunan Pajak (UU PP) merupakan penghapusan pajak yang seharusnya terutang, dan tidak dikenai sanksi administrasi dan pidana perpajakan, dengan cara mengungkap harta dan membayar uang tebusan. Pengampunan pajak diberikan dalam periode sejak UU mulai berlaku hingga 31 Maret 2017 (diperpanjang satu bulan yaitu 30 April). Baik wajib pajak orang pribadi maupun badan diperbolehkan ikut program ini.

Dasar pengenaan uang tebusan adalah harta bersih yaitu selisih antara nilai harta dikurangi nilai utang, yang dihitung berdasarkan nilai wajar. Harta yang harus diungkap adalah akumulasi tambahan kekayaan ekonomis berupa seluruh kekayaan, sedangkan utang adalah pokok utang yang belum dibayar berkaitan langsung dengan perolehan harta. Uang tebusan yang diatur UU ini adalah (i) sebesar 2 persen, 3 persen, dan 5 persen (periode triwulan I, triwulan II, dan triwulan III) bagi wajib pajak yang merepatriasi harta dari luar negeri dan deklarasi dalam negeri, (ii) 4 persen, 6 persen, dan 10 persen untuk wajib pajak yang hanya mengungkapkan nilai harta sampai dengan Rp.10 miliar, dan 2 persen bagi wajib pajak yang mengungkapkan nilai harta lebih dari 10 miliar.

Harta yang direpatriasi tersebut wajib diinvestasikan paling singkat tiga tahun di wilayah Negara Kesatuan Republik Indonesia (NKRI) dan harta yang diungkap di dalam negeri tidak boleh dialihkan ke luar negeri selama tiga tahun. Wajib pajak yang ikut program pengampunan harus melunasi terlebih dahulu seluruh pokok pajak yang belum dilunasi (tunggakan pajak), mencabut restitusi pajak, dan seluruh permohonan terkait sengketa pajak, baik pengurangan atau penghapusan sanksi administrasi, pengurangan atau pembatalan ketetapan yang tidak benar, keberatan, banding, gugatan, atau peninjauan kembali. Bagi wajib pajak yang sedang menjalani pemeriksaan bukti permulaan dan penyindikan pajak dan akan ikut program harus melunasi terlebih dahulu pajak yang tidak atau kurang dibayar.

Fasilitas yang diperoleh wajib pajak yang ikut pengampunan adalah (i) penghapusan pajak terutang yang belum diterbitkan ketetapan pajak, tidak dikenai sanksi administrasi dan sanksi pidana perpajakan sampai dengan akhir tahun pajak terakhir, (ii) penghapusan sanksi administrasi berupa bunga, denda atau kenaikan, (iii) tidak dilakukan pemeriksaan pajak, pemeriksaan bukti permulaan, dan penyidikan pajak, (iv) penghentian, pemeriksaan, pemeriksaan bukti permulaan, dan penyidikan pajak.

Bagi wajib pajak yang tidak jujur mengungkapkan hartanya dikenai Pajak Penghasilan (PPh) sesuai ketentuan yang berlaku dan ditambah sanksi kenaikan 200 persen. Sementara wajib pajak yang tidak ikut program apabila ditemukan harta yang belum dilaporkan akan dianggap tambahan penghasilan saat ditemukan. UU Pengampunan Pajak cukup ringkas dan padat, hanya terdiri dari 13 bab dan 25 pasal. Undang-Undang ini ingin mengatur dengan mudah, sederhana, dan lugas. Resikonya adalah muncul ketidakjelasan dan ruang multitafsir. Untuk itulah peraturan teknis yang jelas, detail, dan komprehensif sebagai turunan undang-undang mutlak diperlukan. Peraturan Menteri Keuangan (PMK) yang terbit tidak boleh membuat norma baru atau menyimpang dari norma dan semangat UU. PMK sebaiknya menjabarkan maksud dan tujuan UU dengan mengatur tata cara dan administrasi yang sederhana, mudah, dan jelas.

1Pengampunan berdasarkan Kamus Besar Bahasa Indonesia (KBBI, 1989:30) berarti pembebasan dari hukuman atau tuntutan. 
Langkah lanjutan setelah disusunnya PMK adalah sosialisasi yang masif baik ke internal Direktorat Jenderal Pajak maupun masyarakat wajib pajak agar kedua belah pihak memiliki pemahaman yang sama. Mengapa demikian? Perpajakan menganut Lex Specialis Derogate Lex Generalis, yang artinya peraturan khusus lebih diutamakan dari pada peraturan umum atau jika sesuatu ketentuan belum atau tidak diatur dalam peraturan khusus, maka akan berlaku ketentuan yang diatur dalam peraturan umum. Dalam hal ini peraturan khusus adalah hukum pajak, sedangkan peraturan umum adalah hukum publik atau hukum lain yang sudah ada sebelumnya. Selanjutnya hukum pajak menganut Paham Imperative, yaitu pelaksanaannya tidak dapat ditunda. Misalnya dalam hal pengajuan keberatan, sebelum ada keputusan dari Direktur Jenderal Pajak bahwa keberatan tersebut diterima, maka Wajib Pajak yang mengajukan keberatan terlebih dahulu membayar pajak, sesuai dengan yang telah ditetapkan. Berbeda dengan hukum pidana yang menganut paham oportunitas, yaitu pelaksanaannya dapat ditunda setelah ada keputusan lain.

Oleh karena itu pemahaman yang sama sangat penting karena fondasi program ini adalah kesalingpercayaan. Wajib pajak butuh jaminan bahwa mengikuti program ini bukan sebuah jebakan yang akan merugikan di kemudian hari. Di pihak lain, pemerintah membutuhkan data yang diungkapkan akurat dan bermanfaat bagi perluasan basis pajak dan penggalian potensi pajak di masa mendatang. Pemerintah juga perlu mendengarkan suara pelaku bisnis agar skema repatriasi dan investasi dapat optimal, karena sejalan dengan praktik bisnis yang lazim. Dengan program pengampunan pajak ini maka era transparansi, membangun sistem perpajakan yang kuat, kredibel, dan akuntabel merupakan sebuah kepastian. Lebih lanjut program ini merupakan sekali untuk jangka waktu yang sangat lama, niat menggerakkan perekonomian, jaminan tidak adanya jebakan bagi wajib pajak, akan menindak mereka yang menyimpang, dan mengiringi program dengan menuntaskan reformasi hukum perpajakan.

Pemerintah memperkirakan program ini akan menambah pendapatan negara dari pajak sekitar Rp. 165 triliun (Warta Pajak, 05 Juli 2016). Periode I program ini yaitu Juli sampai September 2016 Penjelasan jumlah ini termasuk ribuan triliun rupiah aset repatriasi yang akan masuk ke pasar keuangan dan bursa di Indonesia. tambahan aset yang diharapkan bisa ikut mengerakkan perekonomian Indonesia. Wajib pajak peserta pengampunan pajak memperoleh fasilitas penghapusan pajak atas utang pajak yang belum diterbitkan ketetapan pajaknya. Wajib pajak juga bebas dari sanksi administrasi dan pidana perpajakan. Selain itu, tidak dilakukan pemeriksaan pajak, pemeriksaan bukti permulaan, dan penyelidikan tindak pidana perpajakan atas kewajiban perpajakan dalam masa pajak sampai akhir tahun pajak terakhir. Namun, jika wajib pajak menyampaikan data dan informasi harta yang tidak jujur, harta tersebut akan dikenai pajak sesuai aturan ditambah sanksi administrasi.

Tabel 1

Penerimaan Pajak Per 30 September 2016 (dalam Rp Triliun)

\begin{tabular}{|c|c|c|}
\hline Jenis Pajak & Jumlah & APBNP 2016 \\
\hline PN Non Migas & 476,549 & 819,496 \\
\hline PPN \& PPnBM & 270,112 & 474,235 \\
\hline PBB & 15,631 & 17,710 \\
\hline Pajak Lainnya & 5,475 & 7,414 \\
\hline PPh Migas & 24,658 & 36,345 \\
\hline Total & 792,426 & $1.355,203$ \\
\hline
\end{tabular}

Sumber: DJP 2016-2017

Berdasarkan data di atas nampak bahwa antara target yang ditetapkan dengan realisasi masih terdapat "gap" yang sangat mencolok. Hal inilah yang menyebabkan pemerintah harus berpikir lebih untuk dapat menutup realisasi pajak berdasarkan anggaran yang ditetapkan. Di tengah kebuntuan dan kebingungan tersebut, pemerintah memperhatikan langkah cepat untuk mengumpulkan target menutupi defisit negara dan meminimalkan menutup kekurangan (shortfall)yang terlanjur terjadi. Penelitian Togler \& Schaltegger (2001) menyatakan bahwa negara yang berhasil melakukan kebijakan tax amnesty adalah Italia, India dan Afrika Selatan. Sedangkan hasil penelitian Boniello (2003) dan Widodo (2010) menjelaskan bahwa kebijakan tax amnesty yang berhasil dilakukan di India pada tahun 1997 telah mampu menambah pendapatan pajak sebesar 8,05\%. Keberhasilan India mengumpulkan dana untuk menutup defisitnya menjadi suatu yang menarik bagi Pemerintah Indonesia. Harapannya keberhasilan tersebut terjadi juga di Indonesia.

Sebenarnya Indonesia pernah melakukan tax amnesty pada tahun 1984. Motif pemerintah dalam melaksanakan tax amnesty pada saat itu, pertama diberlakukannya sistem perpajakan baru yang mampu meningkatkan peran serta masyarakat dalam pembiayaan negara dan pembangunan nasional. Kedua diperlakukannya keterbukaan dan keju- 
juran dari WP (Ragimun, 2014). Dua alasan ini erat kaitannya dengan implementasi self assessment. Tax amnesty yang diberikan pada dua periode tersebut adalah pengampunan pajak model investigation amnesty, melalui pengampunan ini Direktorat Jenderal Pajak tidak menyelidiki dan menginvestigasi sumber penghasilan yang dilaporkan pada periode historis. Biaya pengampunan yang harus dibayar WP adalah $10 \%$ atau $5 \%$ (tarif reduksi) dari total objek pengampunan (Bagiada \& Darmayasa, 2016). Namun dalam praktiknya, tax amnesty pada tahun 1984 tersebut mengalami kegagalan. Beberapa peneliti antara lain Ragimum (2014) telah melakukan pendalaman yang menganalisa mengapa tax amnesty Indonesia sebelum ini tidak berhasil. Menurutnya, kegagalan tax amnesty yang pernah diterapkan di Indonesia karena tidak didukung oleh sarana dan prasarana yang mendukung, selain itu menurut Tambunan (2015) bahwa tax amnesty pada tahun 1984 mengalami kegagalan karena tidak ada law enforcement tegas pasca tax amnesty. Untuk itu lebih dari satu dekade terakhir Indonesia telah berusaha memperbaiki sistem perpajakannya untuk meningkatkan penerimaan pajak (Arnold, 2012).

Oleh karena itu tax amnesty merupakan bentuk lain asas self assessment dalam melaksanakan kewajiban perpajakannya (tax compliance), dan pada akhirnya untuk penegakan hukum (law enforcement) bagi Wajib Pajak (selanjutnya disingkat WP) itu sendiri maupun bagi petugas pajak (Prasetyo, 2017). Mengapa demikian? Karena pelaksanaan kebijakan ini melembagakan keterbukaan sukarela (voluntary disclosure) dari WP dalam negeri untuk melaporkan harta kekayaan yang dimiliki (sebelumnya di luar negeri), artinya kejujuran WP menjadi tumpuan pelaksanaan pengampunan pajak ini. Untuk menguji kesesuaian antara data dan informasi yang dilaporkan pemohon amnesti dengan keadaan sebenarnya.

Oleh karena itu tujuan dan masalah yang ingin diulas adalah bagaimana program amnesti pajak dijalankan. Ketertarikan penelitian dikarenakan program ini berbeda dengan pemeriksaan pajak yang diatur pada UndangUndang Tentang Kententuan Umum dan Tata Cara Perpajakan (UU KUP), hasil pemeriksaan oleh tim pemeriksan permohonan pengampunan pajak (selanjutnya Penulis menyampaikan amnesti pajak ) bersifat final, dan menjadi dasar keputusan pemberian atau penolakan amnesti pajak pajak. Selanjutnya program ini menunjukkan kerahasiaan data dan informasi hasil amnesti pajak. Mengapa demikian? Perlu diakui bahwa aspek kerahasiaan ini memiliki daya tarik yang kuat untuk meningkatkan jumlah permohonan amnesti pajak. Untuk itu, pemohon amnesti pajak harus mendapat kepastian bahwa laporan harta yang dibuatnya tidak akan diteruskan kepada penegak hukum lainnya untuk penuntutan pidana terhadap kejahatan yang berbeda.

\section{RERANGKA TEORITIS}

Upaya memberikan aspek come clean yang menjadi fasilitas utama dalam kebijakan amnesti pajak harus dikaitkan dengan larangan membocorkan data dan informasi WP sebagaimana diatur dalam UU KUP. Sesuai ketentuan Pasal 41 Ayat (3) bahwa pengaduan terhadap dugaan pelanggaran kewajiban merahasiakan data dan informasi oleh petugas pajak hanya dapat dilakukan oleh orang yang kerahasiannya dilanggar. Mutatis mutandis, artinya pemohon amnesti pajak juga dapat mengadukan pembocoran rahasia oleh tim pemeriksa dan atau petugas pajak lainnya. Oleh sebab itu, penjelasan ini "penting" karena program amnesti pajak merupakan kebijakan jangka pendek, sehingga tidak dapat menyelesaikan permasalahan penghindaran pajak, pengelakan pajak, dan transfer pricing. Antisipasi terhadap ketiga modus perlawanan WP tersebut hanya dapat dilakukan dengan mengubah peraturan perundang-undangan, terutama Undang-Undang tentang Pajak Penghasilan (PPh).

Akhirnya, amnesti pajak merupakan kebijakan realistis yang harus dipilih pemerintah untuk keluar sepenuhnya dari keterpurukan ekonomi nasional. Tercatat dalam www.pajak.go.id periode I amnesti pajak yaitu Juli-September 2016 telah dihasilkan uang tebusan sebanyak Rp. 93 triliun dan jumlah harta dilaporkan sebesar Rp. 3.792 triliun. Jumlah harta tersebut terdiri atas harta repatriasi luar negeri Rp.976 triliun, dan harta deklarasi dalam negeri Rp. 2.674 triliun. Capaian amnesti pajak ini cukup membanggakan dan dinilai oleh banyak pihak sebagai sebuah keberhasilan. Apresiasi dari berbagai kalangan yang disampaikan kepada Pemerintahan Republik Indonesia, baik dari dalam maupun luar negeri. Tak kurang, Menteri Keuangan Sri Mulyani Indrawati (Kompas, Selasa 08 Nopember 2016) menyebutkan bahwa tax amnesty di Indonesia termasuk yang terbaik di dunia dari sisi uang tebusan yang masuk. Hal ini didasarkan pada jumlah raihan harta yang berhasil didapatkan untuk periode I tersebut.

Lebih lanjut, terhadap capaian amnesti ini tidak lantas membuat Pemerintah khususnya Direktorat Jenderal Pajak berpuas diri. Mengapa demikian? Karena mengingat masih ada dua periode 
berikutnya yang masih harus dijalani hingga 30 April 2017. Kegiatan sosialisasi yang melibatkan berbagai pemangku kepentingan dan imbauanimbauan kian gencar dilaksanakan. Sasarannya, tak lain para WP potensial yang belum memanfaatkan haknya mengikuti amnesti pajak. Mereka adalah para WP besar, profesional, penunggak pajak, WP baru, dan para pelaku UMKM.

Pemerintah terus mendorong WP yang belum mengikuti amnesti pajak agar segera memanfaatkan fasilitas ini. Untuk diketahui, angka partisipasi WP pada periode I program ini terbilang sangat minim. Dari sekitar 20 juta WP yang wajib SPT, baru 422 ribu saja yang mengikuti amnesti pajak. Dengan kata lain baru, 2 persen WP yang berpartisipasi dalam program ini. Alhasil, angka partisipasi ini masih sangat mungkin ditingkatkan lagi. Langkah berikutnya memasuki periode II amnesti, yaitu Oktobersampai Desember 2016 Undang-Undang masih menerapkan tarif tebusan yang rendah. WP yang melaporkan harta di dalam negeri atau yang ingin merepatriasi harta yang ada di luar negeri, hanya dikenai tarif $3 \%$. Program ini dilanjutkan sampai 30 April 2017 diharapkan WP mampu mendeklarasikan harta di luar negeri, dikenai tarif 6 persen, sedangkan perhitungan kembali WP atas kekayaan di dalam negeri 5\%. Bahkan, bagi WP kelompok UMKM dengan omzet sampai dengan Rp.4,8 miliar, tarif tebusannya lebih rendah lagi, yaitu $0,5 \%$ persen untuk yang melaporkan harta kurang dari Rp. 10 miliar atau $2 \%$ untuk yang melaporkan harta lebih dari Rp. 10 miliar.

Kebijakan fiskal seperti itu menurut Burton (2009) merupakan respon penurunan defisit anggaran dengan cara menaikkan penerimaan pajak dan bukan dari utang. Sampai kajian tulisan ini negara kita (Indonesia) memiliki kondisi fiskal yang bagus, kredibel, dan berhati-hati (prudent). Rasio defisit APBN dan utang Indonesia dalam kondisi yang aman. Penerimaan pajak terus dipacu dengan kebijkaan fiskal (program amnesti, ekstensifikasi dan intensifikasi), menaikkan basis pajak (tax base) dan kepatuhan pajak. Oleh karena itu konsistensi reformasi perpajakan tetap dijalankan termasuk sumber daya manusia yang tangguh, mulai dari pimpinan hingga tingkat Kantor Pelayanan Pajak (KPP).

Kondisi fiskal tersebut tidak bisa dipisahkan dengan utang. Mengapa demikian? Karena masalah utang dan pajak adalah dua sumber pembiayaan anggaran yang saling melengkapi. Duaduanya dibutuhkan. Penarikan pajak dengan tarif tinggi dan eksesif akan mengurangi kemampuan WP untuk melakukan investasi dan justru akan mengurangi tingkat kepatuhan. Dan, kemampuan WP untuk membayar kewajiban pajak (tax compliance) juga tergantung pada kondisi perekonomian. Jika ekonomi membaik dan bisnis untung, otomatis penerimaan pajak akan naik, demikian juga sebaliknya. Dalam keadaan krisis dan kelesuan sektor riil, dimana dana pajak masih kurang, pnarikan utang adalah alternatif pembiayaan APBN. Namun, penarikan utang yang terlalu besar akan mendorong kenaikan biaya bunga dan beban utang pada masa mendatang. Di sinilah letak dari kebijakan fiskal dengan strategi untuk menyeimbangkan antara pendanaan dari pajak sebagai sumber utama dan utang apabila dibutuhkan.

Maka, kebijakan amnesti pajak memberikan kemandiran negara yang tidak semata-mata berfungsi sebagai sumber pendapatan negara (budgeter), namun memiliki fungsi untuk memindahkan harta (regulern) dari orang kaya kepada orang miskin, memindahkan harta dari negara lain ke Indonesia (repatriasi) sebagai upaya (1) Memperkuat kurs rupiah (dana repratiasi), (2) Meningkatkan cadangan devisa, dan (3) Meningkatkan iklim investasi. Oleh karena itu langkah tax amnesty yang cukup akomodatif inilah yang mengguatkan Penulis untuk menyakinkan bahwa satu lagi fungsi pajak sebagai Demokrasi. Fungsi ini sebagai merujuk pada penjelasan Miraza (2005) yang menyatakan bahwa pajak sebenarnya perwujudan dari suatu kerja sama kekeluargaan khususnya jika dilihat dari sudut fungsi pajak di dalam pengembangan kehidupan masyarakat. Lebih lanjut Tambunan (2015) dan Arnold (2012) menjelaskan bahwa masyarakat mengeluarkan sebagian dari pendapatannya untuk dipakai negara membangun sarana kepentingan umum. Dengan cara ini masyarakat berperan dalam pelaksanaan hidup bernegara dan berbangsa bagi tercapainya suatu masyarakat yang sejahtera.

Selanjutnya tax amnesty tersebut juga menghadirkan fungsi pajak sebagai Redistribusi. Fungsi ini sejalan dengan tekad bahwa selama pembangunan terus dilakukan maka investasi juga perlu sejalan ditingkatkan. Dana investasi ini bersumber dari sektor negara dan sektor swasta. Untuk memenuhi kebutuhan ini maka tidak ada pilihan lain bagi negara terkecuali meningkatkan penerimaan negara dari pajak, bea masuk, dan cukai. Untuk hal ini Pemerintah melakukan pembaharuan sistem pemungutan perpajakan nasional, atas intensifikasi dan ekstensifikasi. Hanya dengan pemungutan pajak yang sempurna dan terbuka, maka sistem distribusi dapat dilaksanakan secara sempurna seperti membiayai pembangunan irigrasi, jalan dan 
waduk, pusat-pusat kesehatan masyarakat, pasar, sarana pendidikan, dan jembatan yang membuka "kantong-kantong" produksi dan lain sebagainya.

Kedua fungsi pajak tersebut di samping budgeter dan regulered menunjukkan pajak merupakan iuran wajib bagi setiap warga negara yang dibayarkan kepada negara, yang dapat dipaksakan dan tidak mendapatkan kontra prestasi secara langsung, yang diatur dengan Undang-Undang serta penggunaannya untuk membiayai penyelenggaraan pemerintahan dan pembangunan. Oleh karena itu program tax amnesty mempertemukan dua pihak yang saling berkaitan yaitu pemerintah dan masyarakat. Keduanya harus saling memahami kewajiban dan haknya masing-masing. Di satu pihak pemerintah tidak dapat begitu saja memaksakan haknya dalam hal memungut pajak sebelum ada kesepakatan dengan rakyat, dan sebaliknya masyarakat yang termasuk obyek pajak tidak dapat begitu saja menghindar dari kewajiban membayar pajak, sementara ia menghendaki agar hidupnya terjamin aman dan tertib serta sejahtera. Selama keseimbangan dapat dilaksanakan maka jumlah tax amnesty yang akan dapat dipungut tidak saja besar, tetapi setiap wajib pajak bersedia melakukan pembayaran kembali dengan senang hati.

Kedudukan pajak sebagai alat bagi kehidupan berbangsa dan bernegara sangat penting. Oleh karena itu dalam pelaksanaan pemungutannya faktor keseimbangan tersebut harus dijaga dengan baik sehingga pembayaran pajak oleh wajib pajak merupakan suatu kesadaran dan kebutuhan. Termasuk dalam pengertian keseimbangan disini adalah adanya unsur keadilan dan pemerataan yang dapat dirasakan oleh setiap Wajib Pajak (WP) melalui pengaturan yang cermat oleh pemerintah (Prasetyo, 2008, 2011, 2016). Fiskus sebagai aparat pemungut pajak harus memahami benar pengertian ini. Keberhasilan fiskus dalam melaksanakan amnesti pajak tercermin dari besarnya pungutan yang dapat dikumpulkan dan tingkat kepuasan yang dapat dirasakan oleh masyarakat. Kedudukan fiskus berada di dua sisi kepentingan yaitu kepentingan pemerintah dan masyarakat, yang kedua kepentingan tersebut harus dijaga dengan baik.

Dengan demikian program amnesti pajak tidak dapat hanya dilihat dari satu sisi saja (yang biasa dipikirkan oleh kebanyakan orang dan mungkin oleh sebagian fiskus) sebagai suatu kewajiban kepada negara. Amnesti pajak dapat pula dilihat dari sisi lain sebagai alat perekonomian yang dapat mensejahterakan masyarakat, sebagai salah satu sumber pembiayaan pembangunan, mendorong pertumbuhan ekonomi lewat kebijakan pembangunan yang berjalan dan itu berarti mampu pula menciptakan kesempatan kerja dan berusaha serta menciptakan sarana perekonomian lainnya yang mempelancar roda perekonomian. Sehingga dua pihak antara pemerintah dan WP memiliki hubungan yang sinergi dalam mencatat dan melaporkan jumlah pajak yang menjadi kewajibannya.

\section{METODE PENELITIAN}

Penelitian kualitatif dengan studi kasus yang digunakan dalam rangka menghadirkan evaluasi program amnesti pajak. Program ini direspon dengan hadirnya PSAK 70 tentang Implementasi Akuntansi Aset (Harta) dan Liabilitas (Utang) Pengampunan Pajak yang mengatur penyajian hasil atas harta dan utang dalam laporan keuangan, dan diperlakukan secara terpisah diluar amnesti pajak. Serta secara rinci memperlakukan penyajian, perhitungan dan aspek keuangan lainnya berkaitan amnesti pajak dalam asas self assesment yang melibatkan peran fiskus dan wajib pajak (WP). Oleh karena itu dilakukan dengan cara wawancara mendalam (Kusworo, 2009; Basrowi dan Soenyono, 2004). Arah wawancara mendalam adalah proses pelaksanaan penelitian ini. Lebih lanjut, untuk alasan privatisasi wawancara para informan meminta untuk menggunakan inisial. Selain wawancara mendalam juga dilakukan pengamatan langsung pada saat pelaksanaan amnesti pajak.

Keterlibatan dua pihak yaitu fiskus dan wajib pajak tersebut menjadi fokus penelitian ini. Pihak fiskus yang diteliti yaitu Kepala Seksi Penagihan dan Pelayanan (Pak W) dan 4 Wajib Pajak Orang Pribadi Badan (WP OP Badan), yaitu WP A, B, C dan D yang terdaftar di di KPP Pratama Kabupaten X. Wawancara dilakukan selama 7 bulan dari tanggal 05 Januari sampai 05Agustus 2017. Wawancara ini bertujuan untuk mengungkapkan pelaksanaanprogram amnesti pajak yang dilaluinya. Wawancara ini menghadirkan suasana yang akrab dan jawaban-jawaban bahasa secara spontan, hal ini sebagai nilai "unik" dan sangat berharga bagi penelitian ini.

\section{ANALISIS DAN PEMBAHASAN}

Dari target penerimaan pajak sebesar Rp.1.284 triliun pada 2017, hingga akhir September baru terealisasi 60 persen (Kompas, 7 Oktober 2017)daerah yang diterima oleh pemerintah Provinsi Banten.

Amesti pajak membuat wajib pajak dituntut membayar pajak sesuai peraturan perpajakan. Undang-Undang Pengampunan Pajak (UUPP), ada dua ketentuan yaitu UUPP memperluas subyek 
amnesti pajak hingga mencakup wajib pajak yang memiliki harta di dalam negeri dan luar negeri tetapi tidak merepatriasikan hartanya dalam rangka amnesti pajak. Kedua, sebagai bentuk sanksi terhadap wajib pajak yang tidak memanfaatkan amnesti pajak untuk melaporkan hartanya dengan benar. Penjelasan ini merujuk dari pernyataan Pak W berikut ini:

"Secara keseluruhan, efektivitas program amnesti pajak memikat para pengempang pajak yang menyembunyikan asetnya di luar negeri sangat rendah. Apabila klaim pemerintah pada April 2016 bahwa ada 11.200 triliun aset WNI diparkir di luar negeri benar adanya, maka tingkat keberhasilan amnesti pajak hanya mencapai 10,52 persen. Karena itu, agenda mendesak yang perlu dilakuakn adalah mengusut tuntas WP tersebut. Mereka harus dipaksa mendeklarasikan atau merepatriasi asetnya dengan tarif tebusan yang tinggi. Sasarannya wajib pajak potensial yang belum memanfaatkan haknya mengikuti amnesti pajak. Mereka adalah para wajib pajak badan, profesional, wajib pajak baru dan para pelaku UMKM."

Pernyataan di atas menunjukkan upaya amnesti pajak untuk melaksanakan UU dan menggali potensi pajak. Hal ini kondisi merupakan upaya untuk terus mendorong WP yang belum mengikuti amnesti pajak agar segera memanfaatkan fasilitas ini. Fasilitas untuk menghindarkan saksi melaporkan perhitungan hartanya yang tidak benar (Tambunan, 2015; Widodo, 2010). Perhitungan harta sangat tergantung dari persepsi WP dengan merujuk pada self assessment dan tax planning. Namun, dalam perjalannya WP mengupayakan adanya loophole dari pelaksanaan UU perpajakan (Prasetyo, 2016). Pemahaman UU Pajak membutuhkan kesadaran bukan paksaan. Merujuk pada pernyataan WP D berikut ini:

"Kalau amnesti pajak Mas...bukan program tapi memberikan catatan pengusaha untuk merespon bagaimna perhitungan pajak yang sudah dilaporkan. Kalau pengelapan bukan tapi...lebih bagaimana saya mengatur jumlah pajak yang harus saya laporkan. Kalau usaha naik turun dan rugi masak harus saya laporkan."

Perhitungan rugi merupakan mekanisme WP untuk menghindari ataupun bisa sebagai upaya pengelapan pembayaran kewajiban perpajakan. Mengapa demikian? Karena penghitungan rugi jelas tidak ada pajak. Metode ini menggunakan teknik income decreasing (melaporkan rugi). Perhitungan ini membuat jumlah pajak yang harus dilaporkan adalah nihil. Selain itu merujuk pada pernyataan WP B di bawah ini:
"Konseptual amnesti pajak memberikan informasi adanya yang tidak beres dalam jumlah pajak yang dilaporkan. Kalau saya melaporkan ya...itu kondisi keuangan saya yang setiap tahun naik dan turun, lah...hal inilah yang membuat saya melakukan perataan jumlah pajak yang dibayar."

Kondisi di atas menunjukkan WP mempunyai kesadaran membayar pajak dengan langkah "mengamankan" apabila terjadi kerugian. Kondisi ini merupakan upaya WP melakukan income smothing. Teknik ini banyak digunakan badan, karena lebih soft dalam memanipulasi laba dengan besaran nilai yang relatif merata dari tahun ke tahun. Tujuannya agar tidak menjadi incaran otoritas perpajakan.

Persoalan klasik di atas menunjukkan kesadaran pembayaran pajak bukan merupakan kesadaran namun keterpaksaan. Tidak semua orang ingin membayar pajak dan banyak celah untuk memanipulasi pajak. Tanpa bermaksud menyerderhanakan, rasio perpajakan Indonesia sebagaimana merujuk pada penjelasan Pak W dan WP D. Pak W menjelaskan bahwa:

“Rasio perpajakan Indonesia, yaitu perbandingan antara penerimaan pajak dan produk domestik bruto, hingga saat ini tak kunjung optimal. Baru mencapai 12,1 persen, berada di bawah Malaysia dan Thailand yang sudah mencapai 17 persen, atau Korea Selatan 24 persen, dan negaranegara anggota OECD sebesar 34 persen."

Selanjutnya penjelasan WP D menyangkut rasio pajak adalah:

"Rasio pajak di Indonesia masih menekankan pada penerimaan, padahal Mas...penerimaan pajak sangat berhubungan dengan kesadaran masyarakat untuk membayar pajak. Kondisi ini masih rendah dari yang diharapkan...program pengampunan pajak itu merupakan contoh untuk terus membuat wajib pajak patuh tanpa sanksi, dan juga menurut saya belum optimalnya pula kinerja institusi perpajakan."

Kedua penjelasan tersebut sejalan dengan hasil penelitian Prasetyo (2011), Prastowo (2012), Rusydi (2013) dan Tambunan (2015) yang menyatakan bahwa kepatuhan dan kesadaran wajib pajak dan kinerja aparatur perpajakan berhubungan dengan kebijakan (tax policy), undang-undang (tax law), dan administrasi (tax administration). Ketiga hal ini mendorong tumbuhnya kedua pihak yang berhubungan dengan penerimaan pajak dalam sistem perpajakan self assesment.

Sistem perpajakan yang baik tersebut akan menurunkan penghindaran dan penyelundupan pajak dan beban pajak berbanding lurus dengan 
kemampuan membayar pajak. Merujuk penjelasan Burton (2009) dan Prastowo (2012) bahwa sistem perpajakan self assesment mencerminkan kesadaran wajib pajak dalam keadilan dengan kesederhanaan administrasi. Hal ini untuk memberikan jaminan kepastian dan kemudahaan dalam melaporakan jumlah pajaknya terlaporkan. Oleh karena itu program amnesti pajak dalam sistem ini memberikan struktur penerimaan pajak berkeadilan. Sebagaimana hal ini dinyatakan oleh WP A berikut:

"Bukan...itu program amnesti namun karena jumlah pajak yang terhitung untuk dilaporkan dalam SPT menjadi saya memikirkan untuk memiliki dana di luar negeri...ide ini muncul karena dana di luar negeri lebih menjamin dan tanpa dipungut pajak."

Prinsip berkeadilan menjadi langkah yang seharusnya ditempuh Direktur Jenderal Pajak (DJP) untuk memperlakukan yang "sama" sistem perpajakan. Amnesti pajak terjustifikasi karena keberhasilan upaya penegakan hukum terhadap WP yang memiliki harta di luar negeri (offshore) ditentukan oleh efektivitas tax collection assistance. Penjelasan ini sebagaimana diatur dalam Persetujuan Penghindaran Pajak Berganda (P3B) dengan negara mitra. Amnesti pajak juga terjustifikasi karena kerangka kerja sama pertukaran informasi (Automatic Exchange of Information/ AEOI) baru akan diimplementasikan pada 2018.

Sebaliknya, upaya penegakan hukum yang dilakukan Direktur Jenderal Pajak (DJP) terhadap wajib pajak yang memiliki harta di dalam negeri tidak memerlukan bantuan atau persetujuan pihak lain, termasuk badan peradilan. Prima facie, perluasan subyek amnesti pajak merupakan bentuk relaksasi penegakan hukum terhadap WP yang memiliki harta di dalam negeri, sehingga ada kesetaraan perlakuan dengan WP yang memiliki harta di luar negeri. Meski demikian, sebagaimana penjelasan WP C sebagai berikut:

"Saya memiliki usaha di sini dan ada di luar...perlu dong saya memiliki bantuan perlindungan hukum bukan sanksi untuk mengejar saya sebagai wajib pajak, namun lebih kepada perbedaan perlakuannya bukan dalam...begini Mas...hukum disini ada amnesti sedangkan pelaporannya tidak. Lha...ini kan merupakan penegakan hukum yang berbeda."

Oleh karena dengan merujuk pada penjelesan WP C tersebut bahwa perlakuan yang identik terhadap keduanya justru mendekatkan pada ketidaksetaraan. Perlu untuk diketahui pada tahun 2015 pemerintah telah menerapkan kebijakan pengurangan atau penghapusan sanksi administrasi sesuai ketentuan yang terdapat pada Pasal 36 UU tentang Kententuan Umum dan Tata Cara Perpajakan (UU KUP). Artinya, tidak ada urgensi untuk memperluas subyek amnesti pajak dalam UU No. 11 Tahun 2016 tentang Pengampunan Pajak (UUPP).

Lebih lanjut, penjelasan bentuk sanksi terhadap WP yang tidak memanfaatkan amnesti pajak untuk melaporkan hartanya dengan benar, UU PP mengkualifikasikan ulang harta yang tidak dilaporkan WP berdasarkan temuan DJP sebagai penghasilan kena pajak yang akan dikenai tarif normal Pajak Penghasilan (PPh). Ketentuan ini tidak sesuai dengan tujuan menciptakan sistem perpajakan yang lebih berkeadilan, karena UU PPh menganut fruit and tree concept, yaitu konsep simbolis yang memisahkan harta, yang diibaratkan sebagai tree, dan penghasilan yang diibaratkan sebagai fruit. Pengenaan tarif PPh terhadap nilai harta akan menimbulkan pajak yang eksesif. Mengapa demikian? Karena pemungutan pajak atas penghasilan yang diperoleh subyek pajak, dan bukan atas harta yang diakumulasikan olehnya. Penjelasan ini merujuk pada pernyataan WP B berikut ini:

"Harta dan utang adalah dua yang menjadi pusat pelaporan dalam SPT. Oleh sebab itu saya...mempunyai penjelasan yok opo SPT iki memberikan informasi kepada wong pajek akan kewajaran akumulasi harta dan utang dengan perolehan penghasilan yang menjadi obyek dan bukan, serta...kuwi Mas...bukan sebagai dasar pengenaan pajak tho..."

Penjelasan WP B memberikan pengertian bahwa UU PP merupakan ketentuan yang tidak "proporsional", karena secara konseptual pajak tidak dapat dikenakan sebagai bentuk sanksi akibat ketidakpatuhan terhadap peraturan perundangundangan. Sebaliknya menurut Kurniawan \& Pamungkas (2006) serta Burton (2009) bahwa pajak dipungut karena seseorang atau badan memenuhi ketentuan-ketentuan yang terdapat pada peraturan perundang-undangan di bidang perpajakan. Dalam konteks pemungutan $\mathrm{PPh}$, sebagaimana di jelaskan Prasetyo (2016) menjelaskan seorang subyek pajak memiliki utang PPh karena memperoleh penghasilan yang jadi obyek PPh, dan bukan karena melanggar UU PPh.

Persoalan utang dan pajak adalah dua sumber pembiayaan anggaran yang saling melengkapi. Dua-duanya dibutuhkan sebagaimana merujuk penjelasan Pak $W$ berikut:

"Penarikan utang dan pajak memberikan ruang sama, yaitu tarif dan eksesif mengurangi 
kemampuan wajib pajak untuk melakukan investasi dan kepatuhan membayar pajaknya. Dan...kemampuan wajib pajak untuk membayar kewajiban pajak juga akan tergantung pada kondisi perekonomiannya, artinya ada hubungan positif dengan APBN."

Penjelasan ini sejalan dengan WP A yang menjelaskan bahwa:

"Untung dan rugi merupakan aspek dalam bisnis, olehnya saya meningkatkan penerimaan atau penurunan. Kondisi ekonomi sangat mempengaruhi naik atau turunnya dalam pemenuhan kewajiban pajak saya buat kontribusi penerimaan negara."

Penjelasan kondisi tersebut sangatlah realistis dengan argumentasi bahwa jika ekonomi membaik dan bisnis untung, otomatis penerimaan pajak akan naik, demikian juga sebaliknya. Dalam keadaan krisis dan kelesuan sktor riil, dimana dana pajak masih kurang, penarikan dana dalam mekanisme utang adalah alternatif pembiayaan APBN. Namun, merujuk pada hasil penelitian Lubis (2007), Handayani (2008), Prasetyo (2008, 2011) dan Rusydi (2013) bahwa penarikan utang yang terlalu besar mendorong kenaikan biaya bunga dan beban utang pada masa mendatang. Di sinilah menurut Prasetyo (2011) letak dari kebijakan fiskal dengan strategi untuk menyeimbangkan antara pendanaan dari pajak sebagai sumber utama dan utang apabila dibutuhkan. Penjelasan ini dinyatakan secara terperinci dengan penerbitan Pernyataan Standar Akuntansi Keuangan (PSAK) 70 tentang Implementasi Akuntansi Aset (Harta) dan Liabilitas (Utang) Pengampunan Pajak.

PSAK 70 mengatur dalam penjelasan bahwa penyajian hasil atas harta dan utang dalam laporan keuangan, dan diperlakukan secara terpisah diluar amnesti pajak. Serta secara rinci memperlakukan Penyajian, Perhitungan dan Aspek Keuangan lainnya yang berkaitan amnesti pajak. Pemahaman penjelasan ini bahwa selisih diletakkan pada tambahan modal disetor (additional paid incapital). Hasilnya,BERDAMPAK POSITIF pada Rasio Utang Terhadap Modal (Debt Equity Ratio /DER) maksimum 4 : 1 . Perbandingan ini untuk memberikan kepastian belanja juga sama pentingnya. Keiinginan belanja yang besar tanpa kepastian pendapatan akan menimbulkan utang dan dis-saving. Prinsipnya adalah jangan sampai besar pasak dari pada tiang.

Mengapa penjelasan di atas demikian? Karena Perusahaan akan meningkatkan utangnya untuk memperbesar modal kerja sehingga investasi dan pinjaman Perbankan akan besar, memperkuat kurs rupiah, dan Cadangan Devisa. Bukankah ini sejalan dengan pernyataan WP C berikut ini:

"Pinjaman di bank sebagai modal setor saya untuk meningkatkan ekspansi dan daya saing perusahaan ini. Utang mendorong biaya dan resiko peminjaman. Tak seperti analisis rasional saja...mengapa utang menjadi kebutuhan saya mencukupi dana, yaitu kurs dan bunga diimbangi dengan keuntungan, namun taksiran investasi atas suasana yang kondusif. Karena tidak cukup hanya di tataran lokalan namun keluar menjadi prioritas saya dengan melihat nilai selisih rupiah dan longgarnya kebijakan terbukanya."

Investasi menjadi prioritas WP dalam merespon amnesti pajak untuk melakukan pemungutan pajak. Investasi dalam aspek keuangan (reksa dana, saham, obligasi) dan properti memberikan hasil pendapatan yang mengguntungkan. Hal ini dibuktikan dengan kajian ulasan Prasetyo (2017) yang menyatakan bahwa aspek amnesti memberikan kelonggaran dalam investasi secara bertahap dan berkelanjutan, sehingga membuat anggaran pemerintah lebih berkesinambungan. Selanjutnya kebijakan yang sejalan dengan Paket Kebijakan Ekonomi Jilid XIII, yaitu (1) Menyebabkan utang yang ditebitkan untuk menutupi defisit tidak terlalu besar, (2) Alokasi dana digunakan untuk pembangunan infrastruktur, (3) Melibatkan BUMN dan Swasta sehingga Valuasi meningkat dan harga saham berpotensi naik, dan (4) Dana Cadangan untuk Properti, namun mengatur pasar Properti.

Oleh karena itu prespektif APBN, utang dan pajak memberikan penjelasan tentang target realisasi pajak. Realisasi pajak di Indonesia baru sekitar 47 Persen dari total potensi yang ada (Fenochietto \& Pessino, 2013; Kuncoro, 2016). Oleh karena itu sekitar 53 Persen dari potensi itu masih terhindar pajak. Digali secara proporsional dan tetap memberikan insentif pajak pada sektor yang dianggap berpotensi besar. Asas proporsional amnesti pajak sebagaimana merujuk pada dialog di bawah ini:

PakW : Proporsional merupakan kunci dari konseptual pemungutan dan kesadaran wajib pajak.

Whedy : Asas proporsional yang bagaimana Pak?

Pak W : Ya...dalam pelaksanaan UU PP...jangan direkam lho ya...ha..ha...

Whedy :Rekam dalam hati dan pikiran Pak W ha...ha...bukankah proporsional untuk penghasilan?

Pak W :Memperoleh pajak penghasilan itu saya luruskan, artinya UU PPnya harus proporsional. 
Whedy : Artinya?

Pak W : Artinya UU ini (sambil menunjukkan UUnya) hanya dapat diwujudkan apabila ketentuan-ketentuan pmberan amnesti pajak seperti istilahnya situ adalah harus sesuai dengan tujuan yang ingin dicapai oleh pengundangan UU PP.

Whedy: Ketepatan mengidentifikasi Pak W menjadi faktornya

Pak W : Lha itu...ketepatan mengidentifikasi subyek amnesti dapat mendekatkan UU PP pada tujuan peningkatan investasi.

Whedy: Investasi dalam pengembalian dana maksudnya?

Pak W : Ya...repatriasi dana offshore, dan secara simultan mengurangi dampak ketidakadilan amnesti pajak terhadap wajib pajak patuh. Meski demikian, pengenaan pajak yang eksesif sebagai bentuk sanksi terhadap amnesti pajak yang melanggar ketentuan pemberian amnesti juga tidak dapat dibenarkan secara konseptual. Oleh karena itu internal dan ekternal harus stimulus.

Whedy: Pemberian rangsangan internal dan eksternal amnesti pajak, menurut Pak W bagaimana?

Pak W :Membuat undang-undang perpajakan yang lebih komprehensif dan ramah bisnis, tetapi bisa menjaring penerimaan pajak secara maksimal. optimal mengali potensi pajak atau belum memiliki Nomor Pokok Wajib Pajak. Ini amnesti Mas...bukan pengampunan ha...ha...ha...

Whedy: Tak terkecuali bebas dari sanksi administrasi dan pidana perpajakan.

Pak W : Lha... iya bukan pengampunan seperti terhukum saja, namun... ya perlu diingat adalah amnesti dapat sebagai alat perekonomian yang dapat mensejahterakan masyarakat, salah satu sumber pembiayaan pembangunan, mendorong pertumbuhan ekonomi lewat kebijakan pembangunan, dan...menciptakan sarana perekonomian

Whedy : Semoga...Amiin...Optimis Dech.

Pak W : Optimis...Dong.

Dialog tersebut mendekatkan UU PP pada tujuan peningkatan investasi untuk mengerakkan perekonomian Indonesia dan kepatuhan wajib pajak atau WP (tax compliance). Kepatuhan WP atas fasilitas amnesti terhadap utang yang belum diterbitkan ketetapan pajaknya. WP juga bebas sanksi administrasi dan pidana serta pemeriksaan, sebagaimana merujuk pada penjelasan WP B berikut ini:

"Pengampunan pajak membuat saya mulai memperhitungkan dan melaporkan lagi pajak yang terhitung, tanpa melekat pemeriksaan pajak atau sanksi"

Penjelasan WP B di atas didukung juga pernyataan Pak W:

“...selain sanksi bagi Wajib pajak juga dibebaskan dari pemeriksaan bukti permulaan dan penyidikan tindak pidana perpajakaan atas kewajiban perpajakan dalam masa pajak sampai akhir tahun pajak terakhir. Namun...jika wajib pajak menyampaikan data dan informasi harta yang tidak jujur, harta tersebut akan dikenai pajak sesuai dengan aturan ditambahi sanksi administrasi. "

Oleh karena itu, amnesti pajak meningkatkan kepatuhan WP dalam integritas, tanggung jawab, kedisiplinan, ketepatan, kerja sama, kejujuran, keberanian, pandangan hidup (visionary). Kepatuhan ini diperlukan untuk mencapai target hasil, pertumbuhan dan keberlangsungan fungsi pajak sebagai Budgeter, Regulern, Demokrasi, dan Redistribusi.

Potensi tersebut berkorelasi dengan sistem self assessment antara WP dan petugas pajak (fiskus). WP menumbuhkan motivasi dan sikap mental aspek perpajakannya, selanjutnya fiskus sebagai aparat pemungut pajak harus memahami benar pengertian amnesti dalam sistem pemungutan pajak ini. Keberhasilan fiskus tercermin dari besarnya pungutan yang dapat dikumpulkan dan tingkat kepuasan yang dapat dirasakan oleh WP. Kedudukannya dua sisi kepentingan yaitu kepentingan pemerintah dan masyarakat, yang kedua kepentingan tersebut harus dijaga dengan baik. Mengapa harus dijaga? Hal ini disebabkan karena persoalan pajak merupakan masalah publik. Pajak menjadi andalan penerimaan negara. Usaha reformasi administrasi pajak melalui amnesti pajak membuahkan hasil. Namun, jika permasalahan kesadaran WP dan transparasi pengawasan belum tumbuh, tidak heran kalau perbandingan penerimaan pajak tidak berbanding lurus dengan Produk Domestik Bruto (PDB).

Pajak diharapkan menjadi wujud kesadaran masyarakat (voluntary compliance) dalam memberikan kontribusi terhadap Negara. Manfaat pajak harus dapat dinikmati oleh pembayar pajak, terutama akses dari pemerintah, baik akses informasi maupun akses ekonomi, termasuk juga pajak harus digunakan secara transparan. Pemerintah harus dapat menunjukkan hasil pajak digunakan untuk membangun infrastruktur, subsidi pendidikan yang dapat dirasakan oleh masyarakat, dan seba- 
gainya. Upaya untuk mewujudkan transparansi atas hasil pelaksanaan dan pemanfaatan, hal ini merupakan pertanggungjawaban yang diberikan undang-undang kepada pemerintah untuk mengatur pengenaan pajak, sehingga diharapkan pemerintah dalam merumuskan kebijakan perpajakan melibatkan wajib pajak (WP) yang terkena dampak dari kebijakan tersebut dapat dimintai pendapat dan persetujuannya. Kalimat ini merupakan hasil penjabaran dari pernyataan WP A berikut:

"Saya hadir sebagai wajib pajak bukan adanya amnesti atau program-program lainnya, namun perhatian pentingnya pengembangan usaha inilah yang membuat saya sebagai wajib pajak. Saya berharap...pajak mampu memberikan pelayanan yang memuaskan bukan penyidikan. Karena pengemplang besarnya adalah perusahaan besar kongkalingkong dengan petugasnya...cukup Gayus lah...yang mencuatkan."

Ke depan, dalam mengukur program amnesti pajak hendaknya pencapaian target penerimaan pajak bukan menjadi ukuran utama. Dalam pelaksanaan, beban target penerimaan pajak menjadi beban psikologis bagi aparat pajak untuk dapat merealisasikannya. Ini lebih tidak realities lagi apabila target penerimaan pajak tersebut kurang realitis. Oleh karena itu, kinerja Direktorat Jenderal Pajak (DJP) dalam program amnesti pajak ini sebaiknya ditentukan dari kualitas pelayanan yang diberikan kepada wajib pajak. Pelayanan yang baik diyakini akan meningkatkan kepatuhan wajib pajak. Lebih lanjut menurut Bentley (1998:1), menjelaskan bahwa kepatuhan wajib pajak yang tinggi dengan sendirinya akan meningkatkan penerimaan pajak, karena hak wajib pajak sama pentingnya dengan Hak Asasi Manusia.

\section{KESIMPULAN}

Tidak ada yang ditakuti oleh Don Vito Corleone, seorang pemimpin mafia di Amerika Serikat selain mati dan pajak (Film The Godfather yang dibintangi Al Pacino).

Amnesti pajak bertujuan untuk meningkatkan penerimaan pajak dan mendorong pengalihan aset di luar negeri ke dalam negeri (repatriasi aset). Tujuan ini direspon dengan penerbitan PSAK 70 tentang Implementasi Akuntansi Aset (Harta) dan Liabilitas (Utang) Pengampunan Pajak. PSAK ini mengatur dalam penjelasan bahwa penyajian hasil atas harta dan utang dalam laporan keuangan, dan diperlakukan secara terpisah diluar amnesti pajak. Serta secara rinci memperlakukan Penyajian, Perhitungan dan Aspek Keuangan lainnya yang berkaitan amnesti pajak. Pemahaman penjelasan ini bah- wa selisih diletakkan pada tambahan modal disetor (additional paid incapital).

Kondisi seperti itu membuat perusahaan akan meningkatkan utangnya untuk memperbesar modal kerja sehingga investasi dan pinjaman perbankan akan besar, memperkuat kurs rupiah, dan cadangan devisa. Hasilnya, Tax Compliance dalam motivasi dan sikap mental wajib pajak melalui integritas, tanggung jawab, kedisiplinan, ketepatan, kerja sama, kejujuran, keberanian, pandangan hidup (visionary). Motivasi dan sikap ini untuk mencapai fungsi pajak sebagai Budgeter, Regulern, Demokrasi, dan Redistribusi dalam amnesti pajak. Keempat fungsi ini sebagai wujud prespektif $\mathrm{Hu}-$ kum-APBN-Utang-Pajak tentang target realisasi pajak, oleh karenanya pajak diharapkan menjadi wujud kesadaran masyarakat (voluntary compliance) dalam memberikan kontribusi terhadap Negara melalui self assessment.

\section{REFRENSI}

Arnold, J. 2012. Improving the Tax System in Indonesia.

Bagiada, I.M \& Darmayasa, I.N. 2016. Tax Amnesty Upaya Membangun Kepatuhan Sukarela. Proceding Simposium Nasional Vokasi Makassar. 12-14 Mei.

Basrowi, M., \& Soenyono. 2004. Teori Sosiologi Dalam Tiga Paradigma. Cetakan 1. Yayasan Kampusina. Surabaya.

Bentley, D. 1998. Taxpayer's Rights. John Wiley \& Sons Ltd. Singapore.

Boniello, G. 2003. Italian Tax Amnesty is Back But on Tougher Terms. Journal of International Taxation, 14(4): 47-51.

Burton, R. 2009. Kajian Aktual Perpajakan. Penerbit Salemba Empat. Jakarta.

Fenochietto, R \& Pessino, C. 2013. Understanding Countries Tax Effort. Journal of Banking and Finance, Vol. 47, hlm 98-109.

Handayani, D. 2008. "Analisis Hubungan Tingkat Kepatuhan Wajib Pajak Orang Pribadi dengan Penerimaan Pajak Pada Kantor Pelayanan Pajak Pekanbaru Senapelan". Jurnal Akuntansi Keuangan dan Bisnis, Vol. 1, No. 1, hlm 1-13.

Kuncoro, H. 2016. Menerobos Mitos Fiskal. Opini. Kompas, Sabtu 17 Desember.

Kurniawan, P., \& Pamungkas, B. 2006. Penagihan Pajak di Indonesia. Penerbit Bayu Media. Malang.

Kuswarno, E. 2009. Metodologi Penelitian Komunikasi Fenomenologi: Konsepsi, Pedoman, dan Contoh Penelitiannya. Penerbit Widya Padjadjaran. Bandung. 
Lubis, I. 2007. "Kesadaran Self Assessment Menuju Good Corporate Government". Majalah Berita Pajak, No.1587:15 Mei.

Miraza, B. 2005. Pajak Dalam Perspektif Ekonomi. Paper. Majalah Berita Pajak.

Prasetyo, W. 2008. "Analisis Tax Planning Pajak Penghasilan Pasal 21 Karyawan Terhadap Pajak Penghasilan Terutang Badan (PPh Pasal 25) (Studi Survei Pada Wajib Pajak Badan Yang Diperiksa Kantor Pemeriksaan dan Penyidikan Pajak Malang". Jurnal Akuntansi Universitas Jember, Vol. 6, N0. 2, hlm 1-22.

Prasetyo, W. 2011. “Pemeriksaan Pajak dan Peranannya pada Kepatuhan Wajib Pajak dan Petugas Pajak". Jurnal Ekonomi Akuntansi dan Manajemen, Vol. X, No. 2, hlm 21-34.

Prasetyo, W. 2016. Menjamin Kepatuhan Wajib Pajak Melalui Penerbitan Surat Tagihan Pajak. Jurnal Akuntansi Multiparadigma, Vol. 7, No. 3 , hlm-.

Prasetyo, W. 2017. Euforia Tax Amnesty. Makalah. Dipresentasikan Pada Kuliah Tamu yang diadakan oleh HMJA PSDKU Universitas Airlangga Banyuwangi, Banyuwangi: 07 Juni.

Prastowo, Y. 2012. Kegagalan Reformasi Pajak? Opini. Kompas, Senin 30 Juli.

Ragimun. 2014. Analisis Implementasi Pengampunan Pajak di Indonesia. www.kemenkeu.go.id.

Rusydi, M.K. 2013. "Pengaruh Ukuran Perusahaan terhadap Aggressive Tax Avoidance Di Indonesia". Jurnal Akuntansi Multiparadigma, Vol. 4, No. 2, hlm 323-329.

Tambunan, R. 2015. Mengupas Sunset Policy dan Tax Amnesty: Senjata Kejar Target Pajak. www.pajak.go.id

Torgler, B., \& Schaltegger, C.A. 2001. Tax amnesties and Political Participation. Public Finance Review, 33 (3): 403-431.

Widodo, W. 2010. Moralitas, Budaya dan Kepatuhan Pajak. Penerbit Alfabeta. Bandung. 